\title{
Characterization and Pathogenicity of Botryosphaeriaceae Fungi Associated with Declining Urban Stands of Coast Redwood in California
}

Srdan G. Aćimović, ${ }^{\dagger}$ Plant Pathology and Plant-Microbe Biology Section, Cornell University, Hudson Valley Research Laboratory, Highland, NY; and Research and Development Laboratory, Arborjet Inc., Woburn, MA; Suzanne Rooney-Latham and Sebastian Albu, Plant Pest Diagnostics Branch, California Department of Food \& Agriculture, Sacramento, CA; and Donald M. Grosman and Joseph J. Doccola, Research and Development Laboratory, Arborjet Inc., Woburn, MA

\begin{abstract}
Coast redwood (Sequoia sempervirens) is among the most widely planted landscape trees in California (CA) but is in decline outside its natural range due to factors including prolonged drought and plant pathogens. We investigated associations of Botryosphaeriaceae fungi with declining coast redwood trees throughout CA. More than 100 samples were collected from 11 coastal and inland locations in CA. Fifty-nine Botryosphaeria-like fungal strains were isolated and 18 were selected for further study. Phylogenetic analysis of ITS and EF-1 $\alpha$ sequence data confirmed the presence of Botryosphaeria dothidea, Neofusicoccum australe, N. luteum, N. mediterraneum, and N. parvum. Pathogenicity testing

showed that although the Neofusicoccum species vary in virulence, all are more virulent that $B$. dothidea. $N$. australe caused the largest lesions, followed by $N$. luteum, $N$. parvum, and $N$. mediterraneum. Of the species recovered, only $B$. dothide $a$ has been previously confirmed as a pathogen of coast redwood in CA. These results confirm that multiple Botryosphaeriaceae species are associated with branch decline and dieback on coast redwood in CA, which agrees with similar studies on woody agricultural crops. Accurate diagnosis of fungal pathogens of coast redwood is important for the development of disease management strategies and may help improve horticultural practices in maintenance of urban stands.
\end{abstract}

Sequoia sempervirens (Lamb. ex. D. Don) Endl., also known as coast or coastal redwood or California redwood, is the sole living species in the genus Sequoia. This evergreen tree in the Cupressaceae family is native to North America and its natural range extends along the coast of southern Oregon into central California. In their native stands and under optimal conditions (i.e., moderate temperatures, high rainfall, and seasonal fog), coast redwood trees have very high growth rates and are regarded as among the world's tallest trees. Mixed coast redwood forests play a crucial ecological role with high rates of carbon sequestration related to large tree sizes and maximum biomass production (Sillett et al. 2010; Stephenson et al. 2014; Van Pelt et al. 2016). Before commercial logging in the 1800s, natural stands of coast redwood covered an estimated 2.1 million acres along the coastal regions of California and southwestern Oregon (Blackburn 2010; Roa 2007). However, timber logging, cultural practices, and environmental changes have reduced native stands by approximately $90 \%$, with only an estimated 198,000 acres remaining today (Farjon and Schmid 2013). Outside the protected areas, coast redwood is considered endangered and populations have been in rapid decline due to changes in management practices, absence of fire after logging, and increasing urbanization (Farjon and Schmid 2013). Decline is promoted by the introduction of invasive plant species, habitat fragmentation, forest conversion into agriculture crops, fire suppression, climate change, drought, altered precipitation patterns, and decreased number of fog days (Herbert 2014).

Coast redwood was designated as California's official state tree in 1937, and remains extremely valued throughout the state (Shearer and Shearer 2002). In some parts of California, coast redwood is one of the most frequently planted trees in the landscape, both along the coast and inland (Downer 2004). Their rapid growth, dense canopies, and evergreen appearance make them highly desirable for landowners. Although they may do well in pockets of areas outside of their native range, coast redwoods are not adapted to most inland areas of central California. The hot, dry summers and low total annual precipitation of the central valley are not conducive for redwood

${ }^{\dagger}$ Corresponding author: S. G. Aćimović; E-mail: acimovic@cornell.edu

Accepted for publication 7 April 2018.

() 2018 The American Phytopathological Society growth. In the last decade, there has been a noticeable decline among redwoods, especially in urban landscapes outside of their native range (Downer 2004). Although a number of different twig, branch, and needle pathogens have been documented on coast redwood, their role in the recent widespread decline has not been confirmed. Phytophthora ramorum, the cause of Ramorum blight on forest coast redwood trees and many other tree species, has been confirmed on coast redwood, but only within $P$. ramorum infested counties, and not in valley locations (Davidson et al. 2008; Fichtner et al. 2007; Maloney et al. 2002, 2005). Other primary and opportunistic pathogens that can infect healthy or stressed coast redwood trees include: $P$. cinnamomi which causes root and crown rot, canker pathogens including Botryosphaeria dothidea, B. ribis, and Cytospora sp., as well as various wood decay and needle blight pathogens (Scharpf 1993; UC IPM 2016). Branch canker caused by Seiridium spp. has so far been reported only on giant sequoia, Sequoiadendron giganteum (Marshall and Zambino 2011).

B. dothidea Ces. \& De Not. (= Fusicoccum aesculi Corda) is considered one of the most common pathogens of coast redwood. This fungus has a very wide host range, including more than 35 agricultural and landscape plants in California and more than 400 hosts worldwide (Downer 2004; Farr and Rossman 2017; Ma and Michailides 2002). B. dothidea was first detected in California on coast and giant redwood in 1986, causing branch cankers on trees outside of the natural ranges (Scharpf 1993; Worrall et al. 1986). Subsequent studies on coast redwood examined in central California forests did not report B. dothidea (Espinosa-Garcia and Langenheim 1990) probably indicating on opportunistic nature of this pathogen, with its occurrence associated primarily on stress-related trees. Recently, $B$. dothidea was reported on giant sequoia S. giganteum in Switzerland (Hänzi et al. 2016). Although B. dothidea can form pseudothecia and ascospores that are dispersed by both wind and water, it primarily reproduces asexually by means of pycnidiospores (conidia) and is dispersed to susceptible wounds and tissue by splashing rain, water from sprinkler irrigation, insects, and birds (Ma and Michailides 2002; Michailides and Morgan 1993; Phillips et al. 2013). Cankers, infected wood and bark tissue, and mummified fruit can serve as sources of primary and secondary inoculum (Sutton et al. 2014).

Between 2010 and 2014, preliminary studies on landscape coast redwoods indicated that other Botryosphaeriaceae species might be involved in severe needle blight, leading to branch canker and ultimately tree decline symptoms, i.e., dieback being observed in urban 
populations of coast redwood (Rooney-Latham, personal communication as cited in Lichter and Evans 2011). Within the last decade, there has also been a significant rise in the incidence and severity of pathogenic Botryosphaeriaceae species in hardwood and conifer forests and urban tree stands, including Neofusicoccum nonquaesitum and $N$. parvum on giant sequoia, S. giganteum (Hänzi et al. 2016; Rooney-Latham et al. 2012) and Diplodia corticola on Quercus spp. (Aćimović et al. 2016a; Dissanayake et al. 2016; Linaldeddu et al. 2017; Lynch et al. 2010; Martin et al. 2017; Moricca et al. 2016; Munck et al. 2017; Úrbez-Torres et al. 2010b). A similar trend has been seen in California agricultural fruit and nut crops, such as grapevines, English walnuts, pistachios, olives, and almonds, including numerous new pathogen host records for many Botryosphaeriaceae species (Chen et al. 2014a, b; Inderbitzin et al. 2010; Moral et al. 2010; Úrbez-Torres et al. 2010a, b). Accurate species identification of closely related Botryosphaeriaceae is often difficult and unreliable based solely on morphology and typically multilocus DNA sequence analysis is used for species confirmation (Lazzizera et al. 2008; Moral et al. 2010; Slippers et al. 2006, 2014).

The objectives of this study were to identify and evaluate pathogenicity of Botryosphaeriaceae fungi isolated from symptomatic coast redwood trees throughout California using molecular techniques and
Koch's postulates, respectively. Accurate identification of coast redwood canker pathogens is critical for the development of disease management strategies in landscapes including improved horticultural practices.

\section{Materials and Methods}

Collection and isolation of fungi. Between 2010 and 2014, more than 100 branch and foliar samples of coast redwood trees with visible needle blight and cankers (Table 1) were collected from eight counties of coastal, central, and southern California (Figs. 1 and 2). Samples were rinsed with tap water for 2 min to remove any excess soil and then surface sterilized with $95 \%$ ethanol for $15 \mathrm{~s}$ or $0.6 \%$ sodium hypochlorite for 1 to $2 \mathrm{~min}$. Tissue pieces (approximately 3 to $4 \times 1$ to $2 \mathrm{~mm}$ ) from healthy to diseased margins were plated on full-strength potato dextrose agar (PDA) (Difco Laboratories Detroit, MI), or in some cases half-strength acidified PDA (aPDA) to $\mathrm{pH}$ 4.8. PDA plates were first kept in the dark and then moved to diurnal light after 5 to 7 days. aPDA plates were incubated under constant light. All plates were incubated at $25^{\circ} \mathrm{C}$ and monitored for fungal growth. Eighteen suspect Botryosphaeriaceae colonies were transferred to PDA or aPDA to obtain pure cultures for further studies.

Table 1. Neofusicoccum spp. and Botryosphaeria dothidea isolates from declining coast redwood trees in California that were used for phylogenetic and pathogenicity studies

\begin{tabular}{|c|c|c|c|c|c|c|}
\hline \multirow[b]{2}{*}{ Species } & \multirow[b]{2}{*}{ Isolate } & \multirow[b]{2}{*}{ Location and county in California } & \multirow[b]{2}{*}{ Date of collection $(\mathbf{m} / \mathbf{d} / \mathbf{y})$} & \multirow[b]{2}{*}{ Isolated from } & \multicolumn{2}{|c|}{ GenBank accession no. } \\
\hline & & & & & ITS & EF-1 $\alpha$ \\
\hline N. australe & G15-148 & San Marino, Los Angeles & $12 / 9 / 2014$ & Branch canker & KY711215 & KY818902 \\
\hline N. australe & G15-152 & Pomona, Los Angeles & $12 / 8 / 2014$ & Branch canker & KY711216 & KY818903 \\
\hline N. australe & G15-192 & Descanso, San Diego & $12 / 9 / 2014$ & Needle & KY711217 & KY818904 \\
\hline N. australe & CDFA-72 & Davis, Yolo & $6 / 8 / 2010$ & Branch canker & KY711218 & KY818905 \\
\hline N. australe & CDFA-133 & San Mateo, San Mateo & $2 / 25 / 2013$ & Branch canker & KY711219 & KY818906 \\
\hline N. australe & CDFA-182 & Dublin, Alameda & $5 / 5 / 2014$ & Branch canker & KY711220 & KY818907 \\
\hline N. luteum & G15-143 & Pomona, Los Angeles & $12 / 8 / 2014$ & Needle base $\mathrm{a}^{\mathrm{a}}$ & KY711210 & KY818897 \\
\hline N. luteum & G15-144 & San Marino, Los Angeles & $12 / 9 / 2014$ & Needle base & KY711211 & KY818898 \\
\hline N. luteum & G15-158 & San Marino, Los Angeles & $12 / 9 / 2014$ & Needle & KY711212 & KY818899 \\
\hline N. luteum & G15-187 & Pasadena, Los Angeles & $12 / 9 / 2014$ & Branch canker & KY711213 & KY818900 \\
\hline N. luteum & CDFA-85 & San Marcos, San Diego & $5 / 18 / 2011$ & Twig & KY711214 & KY818901 \\
\hline N. mediterraneum & G15-190 & Descanso, San Diego & $12 / 9 / 2014$ & Needle & KY711221 & KY818910 \\
\hline N. mediterraneum & G15-169 & Modesto, Stanislaus & $12 / 11 / 2014$ & Branch canker & KY711222 & KY818908 \\
\hline N. mediterraneum & CDFA-174 & Davis, Yolo & $4 / 4 / 2014$ & Branch canker & KY711223 & KY818909 \\
\hline N. parvum & CDFA-137 & San Rafael, Marin & $8 / 1 / 2013$ & Branch canker & KY711224 & KY818911 \\
\hline B. dothidea & G15-160 & Pomona, Los Angeles & $12 / 8 / 2014$ & Needle base & KY711225 & KY818912 \\
\hline B. dothidea & G15-189 & Descanso, San Diego & $12 / 9 / 2014$ & Needle & KY711226 & KY818913 \\
\hline B. dothidea & CDFA-122 & Auburn, Placer & $11 / 5 / 2012$ & Twig & KY711227 & KY818914 \\
\hline
\end{tabular}

a Transition from needle base to shoot.

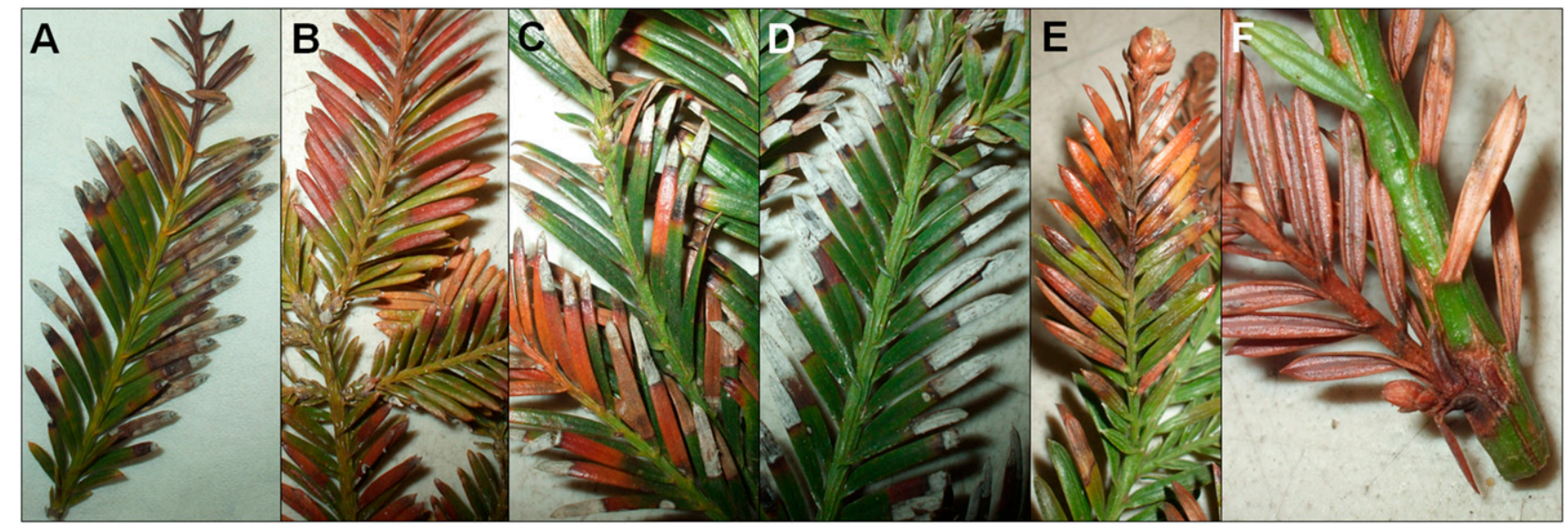

Fig. 1. Needle and shoot blight symptoms on coast redwood caused by Botryosphaeriaceae fungi from different cities in California: A, San Marino; B, Pomona; C, Descanso; D, Pasadena; E, Modesto; F, Pasadena. 
PCR identification and phylogenetic analyses. DNA from the 18 Botryosphaeriaceae cultures was obtained by excising a 2- $\mathrm{mm}^{3}$ agar piece from actively growing colonies and extracted as described with the Qiagen DNeasy Plant Mini Kit protocol (Valencia, CA). The rDNA of the internal transcribed spacer (ITS1-5.8s-ITS2) region was amplified with primers ITS1 and ITS4 (White et al. 1990) using a Bio-Rad C1000 Touch Thermocycler (Bio-Rad Laboratories, Hercules, CA). PCR reactions were performed using the following parameters: an initial denaturation for $5 \mathrm{~min}$ at $94^{\circ} \mathrm{C}$, followed by 34 cycles of: $1 \mathrm{~min}$ at $94^{\circ} \mathrm{C}, 1 \mathrm{~min}$ at $50^{\circ} \mathrm{C}$, and $1 \mathrm{~min}$ at $72^{\circ} \mathrm{C}$. A final extension of $72^{\circ} \mathrm{C}$ was done for $5 \mathrm{~min}$. Amplification of a portion of the elongation factor 1-alpha gene $(\mathrm{EF}-1 \alpha)$ was obtained using primers EF728 and EF968 (Carbone and Kohn 1999; Phillips et al. 2013), using the following parameters: an initial denaturation for $2 \mathrm{~min}$ at $96^{\circ} \mathrm{C}$, followed by 35 cycles of: $30 \mathrm{~s}$ at $94^{\circ} \mathrm{C}, 30 \mathrm{~s}$ at $54^{\circ} \mathrm{C}$, and $30 \mathrm{~s}$ at $72^{\circ} \mathrm{C}$. A final extension of $72^{\circ} \mathrm{C}$ was done for $7 \mathrm{~min}$. The PCR products were purified using the Qiagen QIAquick PCR Purification Kit (Valencia, CA) and direct sequenced with the amplification primers by GeneWiz (South Plainfield, NJ) or Eurofins Genomics LLC through the University of Florida's Plant Diagnostic Center at the Institute of Food and Agricultural Sciences.

Sequences of both loci for the 18 strains were deposited into GenBank (Table 1). Percent nucleotide similarity values were compared with sequences from mostly type specimen strains of
Botryosphaeriaceae from previous studies (Berraf-Tebbal et al. 2014; Zhang et al. 2017). The ITS and EF-1 $\alpha$ sequences of our 18 Botryosphaeriaceae isolates from California were aligned with 10 GenBank sequences of the same genes of Botryosphaeriaceae species (Table 2).

Nucleotide sequences were assembled and edited in Sequencher v5.3 (Gene Codes Corp., Ann Arbor, MI) and putative identifications were made based on percent shared identity of consensus sequences to related fungi in the NCBI GenBank database using a BLASTn search. Multiple sequence alignments were constructed in MEGA v7.0.26 (https://www.megasoftware.net) (Tamura et al. 2013), using the MUSCLE (Edgar 2004) algorithm and were curated in GBlocks v0.91b (Castresana 2000; Talavera and Castresana 2007) using less stringent parameters. jModelTest2 (Darriba et al. 2012; Guindon and Gascuel 2003) was used to determine the best-fit nucleotide substitution model for EF-1 $\alpha(\mathrm{HKY}+\mathrm{I})$ and ITS $(\mathrm{K} 80+\mathrm{I})$ according to corrected Aikake's information criterion (AICc). Evolutionary relationships within the target Botryosphaeriaceae were estimated from phylogenetic analyses of independent gene trees and concatenated datasets using maximum likelihood (ML) and Bayesian inference (BI) within the Cyberinfrastructure for Phylogenetic Research (CIPRES) portal (Miller et al. 2010). ML trees were generated using RAxML (Stamatakis 2006) on XSEDE v8.2.10, specifying a GTRCAT evolutionary model with 1,000 bootstrap replicates. BI
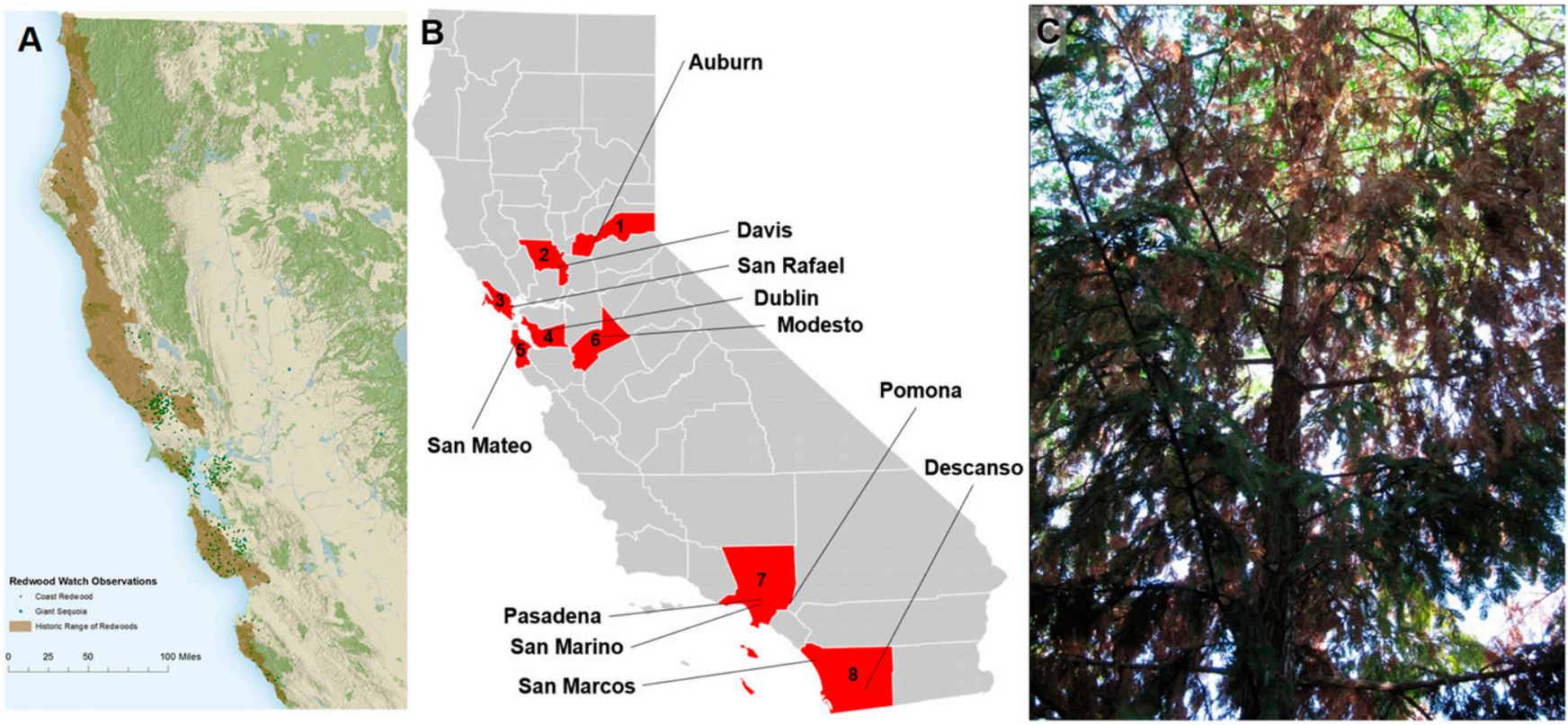

Fig. 2. A, Natural range of Sequoia sempervirens in California and Oregon in light brown (Source: savetheredwoods.org). B, Locations and counties of California where samples were collected from declining coast redwood trees during this study: 1, Placer; 2, Yolo; 3, Marin; 4, Alameda; 5, San Mateo; 6, Stanislaus; 7, Los Angeles; 8, San Diego. C, Decline and canker symptoms of coast redwood tree in the urban landscape of California.

Table 2. Sequences of the type (in bold) and non-type specimens of Neofusicoccum spp. and Botryosphaeria dothidea from GenBank used in the phylogenetic analysis

\begin{tabular}{|c|c|c|c|c|c|}
\hline \multirow[b]{2}{*}{ Species } & \multirow[b]{2}{*}{ Isolate } & \multirow[b]{2}{*}{ Host } & \multirow[b]{2}{*}{ Origin } & \multicolumn{2}{|c|}{ GenBank accession no. } \\
\hline & & & & ITS & EF-1 $\alpha$ \\
\hline N. australe & CMW 6853 & Sequoiadendron $\mathrm{sp}$. & Australia & AY339263 & AY339271 \\
\hline N. australe & CMW 6837 & Acacia sp. & Australia & AY339262 & AY339270 \\
\hline N. luteum & CBS 110299 & Vitis vinifera & Portugal & AY259091 & AY573217 \\
\hline N. luteum & CBS 110497 & Vitis vinifera & Portugal & EU673311 & EU673277 \\
\hline N. mediterraneum & CBS 121718 & Eucalyptus sp. & Greece & GU251176 & GU251308 \\
\hline N. mediterraneum & CBS 121558 & Olea europaea & Italy & GU799463 & GU799462 \\
\hline N.parvum & CMW 9081 & Actinidia deliciosa & New Zealand & AY236943 & AY236888 \\
\hline N. parvum & CBS 110301 & Vitis vinifera & Portugal & AY259098 & AY573221 \\
\hline B. dothidea & CBS 115476 & Prunus sp. & Switzerland & AY236949 & AY236898 \\
\hline B. dothidea & CBS 110302 & Vitis vinifera & Portugal & AY259092 & AY573218 \\
\hline
\end{tabular}


was performed using MrBayes v3.2.6 (Huelsenbeck and Ronquist 2001; Ronquist and Huelsenbeck 2003; Ronquist et al. 2012) using parameters specified in Albu et al. (2016). Briefly, four iterations of 10 million generations each were run with four Metropoliscoupled Chains heated to a temperature of 0.15 . Trees were sampled every 1,000 generations with a burn-in fraction of 0.25 . Trees were rooted to $B$. dothidea and visualized in FigTree v1.4.0 (http:// tree.bio.ed.ac.uk/software/figtree) and phylograms were edited in Inkscape v0.92 (https://inkscape.org).

Pathogenicity tests. Pathogenicity of the 18 Botryosphaeriaceae fungal isolates was tested on potted (3.79 liter) S. sempervirens saplings, with 0.4 to $0.7 \mathrm{~cm}$ trunk diameter at soil line. Three saplings were inoculated with each isolate. Inoculations were conducted by making a rectangular $(1.0 \times 0.3 \mathrm{~cm})$ bark sleeve incision on the main stem. Bark was peeled back to expose the sapwood but remained attached at one end. Mycelial plugs $\left(4 \mathrm{~mm}^{2}\right)$ were taken from the leading margins of 5-day-old cultures and placed on the exposed sapwood, with the mycelium side against the vascular tissue. Uncolonized PDA plugs were placed on wounds of three control saplings, using the same procedure. The bark incisions were wrapped with Parafilm (Bemis NA, Neenah, WI) and placed in a $25^{\circ} \mathrm{C}$ growth chamber with a 12-h photoperiod. After 17 days, most inoculated trees began to exhibit dark brown necrosis and stem girdling (canker) at the inoculation site leading to an overall wilting of the foliage above the inoculation point. No necrosis and no foliar symptoms were seen on the controls. After 21 days, the length of necrosis was measured before destructively sampling the trees for pathogen isolation. Tissue pieces (approximately 3 to $4 \times 1$ to $2 \mathrm{~mm}$ ) were plated on aPDA and incubated at $23^{\circ} \mathrm{C}$.

Statistical analysis. Pathogenicity test data were analyzed after square root transformation, using the MIXED procedure in SAS Studio (SAS Institute, Cary, NC). While normality of residuals was met, grouping of treatments (isolates) into three groups based on unequal residual variances allowed significant model improvement by reduction of AIC and BIC criteria. After the $F$-test was conducted, the main effect of the isolate on canker lesion size was analyzed using the LSD test $(\alpha=0.05)$.

\section{Results}

Collection and isolation of fungi. A total of 70 isolates of Botryosphaeriaceae were recovered from symptomatic coast redwood samples collected throughout California (54.9\% were isolated from blighted needles and $45.1 \%$ from wood cankers). Colonies were divided into six groups based on colony morphology. Most fungal colonies grew rapidly with white aerial mycelium that turned dark olive to pale green after 5 to 7 days at $25^{\circ} \mathrm{C}$, and in reverse turned dark green to black. Although colonies showed varying degrees of aerial mycelium and were different shades of green, general morphological characters resembled those of members of the Botryosphaeriaceae.

PCR identification and phylogenetic analyses. Eighteen of the 70 isolates were selected for further PCR analyses and pathogenicity testing to reflect a proportionate abundance of different Botryosphaeriaceae colony morphologies (Table 1). All isolates have been stored in the fungal collection of the Plant Pest Diagnostics Branch at the California Department of Food \& Agriculture in Sacramento, CA. Although B. dothidea was the only species previously associated with coast redwood canker and dieback, four other Botryosphaeriaceae species were confirmed in this study (Table 1). In addition to B. dothidea, four Neofusicoccum species were confirmed using phylogenetic analyses of a portion of the gene encoding EF- $1 \alpha$ and the ITS region. All four Neofusicoccum species, N. australe, N. luteum, $N$. parvum, and $N$. mediterraneum, are novel associations with coast redwood. $N$. australe and $N$. mediterraneum were more widespread, detected in both northern and southern California in our study, while $N$. luteum was found only in southern California and N. parvum was found only in northern California. Tree topologies resulting from ML and BI analyses of independent alignments of ITS, a portion of the EF- $1 \alpha$ gene and a concatenated data set containing both loci were congruent, with moderately to strongly supported species-level clades for N. parvum, N. australe, and N. luteum. N. mediterraneum was supported as a single lineage on the BI, but not on the ML topology, with the five isolates segregating into two subclades. CBS 121718 (type strain; eucalyptus, Greece) and G15-190 (redwood; Descanso, San Diego) comprised one subclade, while CDFA 174 (redwood; Davis, Yolo), G15-169 (redwood; Modesto, Stanislaus), and CBS 121558 (olive; Italy) comprised the other (Fig. 3).

Pathogenicity tests. Isolates of Neofusicoccum spp. showed different levels of virulence on coast redwood saplings (Fig. 4). S. sempervirens trees inoculated with $N$. australe showed the largest lesion lengths, with a mean length of $17.5 \mathrm{~cm}$ for all isolates and up to 21.3 $\pm 2.3 \mathrm{~cm}$ for the most virulent isolate G15-152. Lesions on saplings inoculated with all $N$. luteum isolates averaged $10.2 \mathrm{~cm}$ and up to $16.5 \pm 2.7 \mathrm{~cm}$ for the most virulent isolate G15-187. The $N$. parvum and $N$. mediterraneum isolates had lesions that averaged 11.9 and $9.9 \mathrm{~cm}$ in length, respectively. The most virulent $N$. mediterraneum isolate, G115-169, caused lesions up to $11.4 \pm 1.8 \mathrm{~cm}$ in length. Lesions for the $B$. dothidea isolates averaged $2.6 \mathrm{~cm}$ but were still significantly greater than the control $(0.7 \mathrm{~cm})$. All the Neofusicoccum spp. isolates caused significantly larger lesions than the $B$. dothidea isolates (Fig. 4). All Botryosphaeriaceae isolates were successfully reisolated from inoculated trees, and confirmed by ITS PCR sequencing, completing Koch's postulates.

\section{Discussion}

This study confirms the presence of multiple Botryosphaeriaceae fungi associated with coast redwood canker and dieback in California. Five different Botryosphaeriaceae species were detected from declining urban stands including $N$. australe, $N$. luteum, $N$. mediterraneum, $N$. parvum, and B. dothidea. Prior to this work, only $B$. dothidea had been associated with coast redwoods (Worrall et al. 1986). However, our findings of multiple Neofusicoccum species support the trend of an increasing incidence of Botryosphaeriaceae pathogens in California's landscape and agriculture trees (Chen et al. 2014a, b; Lawrence et al. 2017; Lynch et al. 2010, 2013; McDonald et al. 2009; Moral et al. 2010, 2017; Úrbez-Torres et al. 2010a, b). Although precipitation is variable from year to year, California experienced severe drought conditions statewide between 2012 and 2016, including the driest four years on record (2012 to 2015; https://ca.water.usgs.gov/california-drought/california-droughtcomparisons.html). Trees subjected to stress, including drought, are known to be more susceptible to Botryosphaeriaceae pathogens (Golzar and Burgess 2011; Schoeneweiss 1981; Slippers et al. 2005). Pathogenicity experiments showed that all of the Neofusicoccum species are able to cause vascular discoloration on coast redwood. To our knowledge, these are the first reports of these four Neofusicoccum species as pathogens of coast redwood in California, including the first report of $N$. mediterraneum as a pathogen of coast redwood. $N$. australe and $N$. luteum were recently isolated from coast redwood outside of its natural range, in Portugal (Alves et al. 2013), while N. parvum was isolated from coast redwood in Serbia (Zlatković et al. 2016a). The four Neofusicoccum species detected in the study differed in virulence between isolates and species, though all of the isolates were significantly more virulent than B. dothidea.

$N$. australe, $N$. luteum, and $N$. parvum cause avocado branch canker in California (McDonald et al. 2009) and N. mediterraneum has been found to cause shoot blight on ash, canker disease of grapevine, branch dieback of olive, and panicle and shoot blight of pistachio (Chen et al. 2014b; Moral et al. 2010, 2017; ÚrbezTorres et al. 2010b). B. dothidea causes branch canker on olive and Botryosphaeria panicle and shoot blight of pistachio (Chen et al. 2014b; Michailides 1991; Úrbez-Torres et al. 2013), while Diplodia seriata causes shoot blight on olive, pistachio, and black fruit rot of quince (Moral et al. 2010). Lasiodiplodia theobromae, N. australe, $N$. luteum, and $N$. parvum were found to be highly virulent canker and dieback pathogens of grapevine, while $B$. dothidea was intermediately virulent on the same host (Úrbez-Torres and Gubler 2009; Úrbez-Torres et al. 2010a). B. dothidea, D. mutila, D. seriata, $N$. mediterraneum, and $N$. parvum were found to cause stem canker, shoot and twig blight, and necrotic leaf lesions on English walnut 
in California (Chen et al. 2014a). N. parvum was the most virulent species in their study, followed by $N$. mediterraneum and B. dothidea. In our study, $N$. australe was found to be the most virulent pathogen of coast redwood, followed by N. luteum, N. parvum, and $N$. mediterraneum. B. dothidea was the least virulent species in our study.

Many different environmental and biological factors may be causing or contributing to the sharp increase in the number of new Botryosphaeriaceae detections in California. Between 2006 to 2010 and again between December 2011 and March 2017, California experienced two of the most extreme droughts in historical records (Jones 2015). The driest period in this state's record-keeping history occurred between late 2011 and 2014 (Hanak et al. 2016). A total of 102 million trees died across 7.7 million acres of forest due to prolonged drought between 2011 to 2016, with 62 million dead trees solely in 2016 (Deamer 2016). In Europe and other parts of the world, a connection is drawn between the rising incidence of Botryosphaeriaceae fungi and the environmental stresses imposed on different forest ecosystems and associated to global climate change (Crous et al.

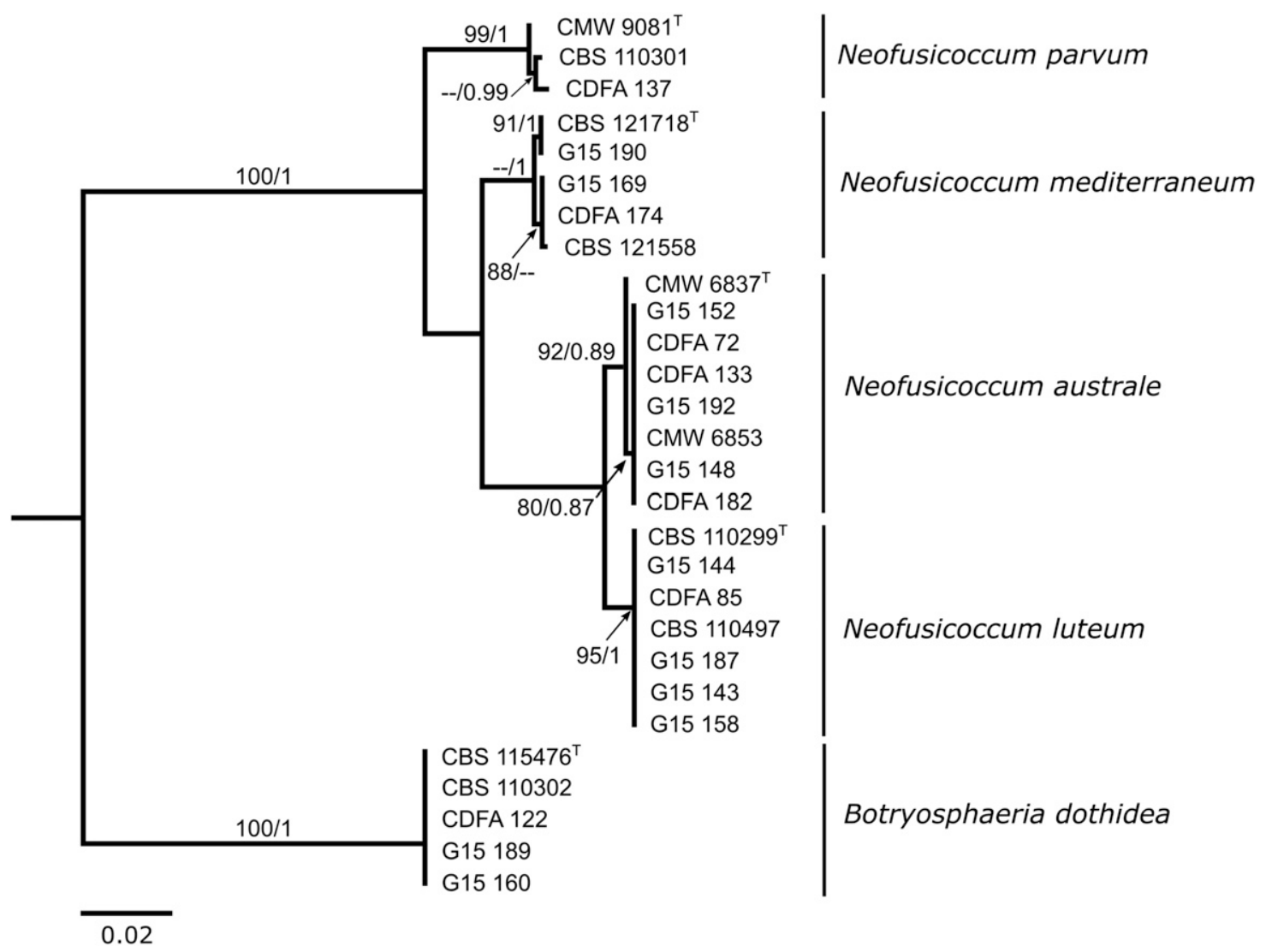

Fig. 3. Maximum likelihood topology depicting evolutionary relationships of four species of Neofusicoccum based on a concatenated alignment of ITS and EF-1 $\alpha$ nucleotide sequences. Tree is rooted with Botryosphaeria dothidea. Support values at nodes represent RAxML bootstrap percentages $>80$ and Bayesian posterior probabilities $>0.85$. Scale bar below the tree indicates number of substitutions per site. Superscript ${ }^{\top}$ indicates isolate is the type specimen for the given species.

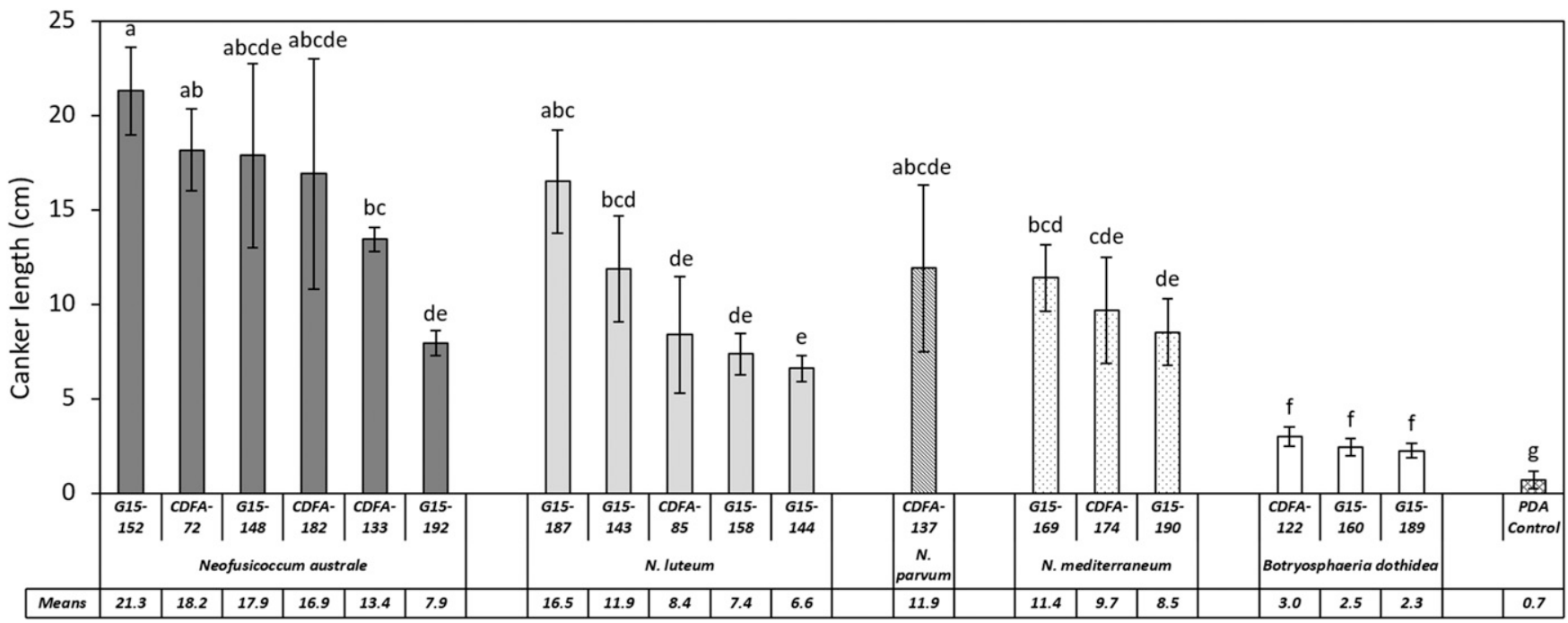

Fig. 4. Average stem lesion length $(\mathrm{cm})$ of coast redwood saplings inoculated with different Botryosphaeriaceae isolates from California. Each mean consists of three replicate trees. Bars followed by different letters are significantly different (LSD test, $P<0.05)$. Error bars represent standard error of the mean. 
2017; Moricca et al. 2016; Panzavolta et al. 2017; Zlatković et al. 2016b).

Research has shown that among other stressors, drought stress is one of the most important environmental factors in predisposing different tree species to infection by opportunistic fungi, including B. dothidea (Ma et al. 2001; Schoeneweiss 1981; Wene and Schoeneweiss 1980). Potted tree and shrub species that were predisposed to different levels of water stress and then inoculated with $B$. dothidea, showed an increase in fungal colonization when water potential declined below -12 to -13 bars (Schoeneweiss 1975). In this trial, wilt symptoms were not evident on the plants until the water potential declined to -15 to -18 bars. In a separate study, it was shown that woody stems were not predisposed to fungal infection unless the duration of water stress, at or below a certain water potential threshold, lasted for more than 3 days (Wene 1979). If the stress was relieved 3 to 5 days after it occurred in this study, the infection predisposition status was reversible and the turgid tissues again became resistant to fungal infection. Similarly, on large landscape trees exposed to short droughts, cankers caused by opportunistic pathogens often cease in progress or heal after the irrigation has started (Schoeneweiss 1981). Prolonged droughts that last several years can lead to static or irreversible state of infection predisposition, allowing otherwise weak pathogens to cause severe tree mortality in forests and urban landscapes (Schoeneweiss 1981; Tobiessen and Buchsbaum 1976). Prolonged droughts in California between 2000 and 2016 may have been the key contributor to an unprecedented increase in incidence and detection of Botryosphaeriaceae fungi. Large numbers of infected trees may have facilitated excessive accumulation of inoculum from different Botryosphaeriaceae fungi over the years, leading to increased spread of these pathogens to susceptible hosts. In our pathogenicity tests, Neofusicoccum species were capable of infecting young, healthy coast redwood trees without exposure to any form of environmental stress. This supports the findings that Neofusicoccum species can infect and cause disease on unstressed Fraxinus species, grapevines, olive, pistachio, and English walnut (Chen et al. 2014a, b; Moral et al. 2010, 2017; Úrbez-Torres et al. 2010b). Contrary to studies on agricultural hosts where $B$. dothidea was showed to possess intermediate to high levels of virulence (Chen et al. 2014a, b; Úrbez-Torres and Gubler 2009), our B. dothidea isolates were less virulent on coast redwood, indicating on potential genetic differences in our strains or a need for some type of environmental stress, such as high temperatures, in order for $B$. dothidea to cause severe disease on coast redwood (Yan et al. 2018). However, it is also possible that different strains of $B$. dothidea vary in virulence, depending on genetic variability and host species and/or cultivar (Chen et al. 2014a, b; Hänzi et al. 2016; Niekerk et al. 2004; Úrbez-Torres and Gubler 2009).

In general, species clades were well-supported in the ML and BI analyses of each individual locus and the concatenated data set. Though we did observe some genetic variation at one or both loci among isolates within the N. mediterraneum, N. australe, and N.parvum clades (Fig. 3), EF-1 $\alpha$ and ITS sequence similarity among all isolates within each clade was $99 \%$ or greater, indicating that the observed variability was intraspecific. Our $N$. mediterraneum isolates from coast redwood in California (CDFA174, G15-169, and G15190) formed a single EF-1 $\alpha$ haplotype that was distinct from the two European isolates collected from other hosts (CBS 121718 and CBS 121558). Previous phylogenetic analyses of Botryosphaeriaceae showed that strains of $N$. mediterraneum from olive and ash in the U.S.A. and Spain formed up to six haplotypes, indicating the potential for substantial genetic variability within this species (Moral et al. 2010). Similarly, McDonald and Eskalen (2011) suggested the possibility of cryptic species by showing that isolates collected from avocado formed subclades within N. parvum and N. australe (Pavlic et al. 2009; Sakalidis et al. 2011). In this study, all of the N. australe isolates from coast redwood in California and also isolate CMW6853 (from $S$. giganteum) formed a single haplotype that differed from the type strain (CMW6837; Acacia sp.) by only a single base. Sakalidis et al. (2011) found a single dominant ITS genotype of $N$. australe present worldwide and also noted that 12 rare or moderately rare genotypes exist. This could potentially explain the lack of genetic variability of $N$. australe isolates on coast redwood in California.

In addition to proper water management in coast redwood stands, other cultural practices that reduce stress should also be addressed to prevent decline. Proper mulching and practices that reduce soil compaction may also help decrease stress and subsequent Botryosphaeriaceae infections (Dirr 1990; Sinclair and Lyon 2005). Removing infected branches before the pathogen reaches the main bole is critical for disease management and also important for reducing inoculum levels within the stand (Sinclair and Lyon 2005; Sutton et al. 2014). Botryosphaeriaceae fungi are known to colonize and infect susceptible pruning wounds of many different hosts (Amponsah et al. 2012; Elena and Luque 2016; Sinclair and Lyon 2005; Úrbez-Torres and Gubler 2011). Pruning should be done during drier periods when there is less inoculum and when pruning wounds heal more quickly in order to prevent infection by water splashed spores of Botryosphaeriaceae (Rolshausen et al. 2010; Úrbez-Torres and Gubler 2011). Currently, there are only few registered fungicides available to landscape managers and arborists against Botryosphaeriaceae species. These are in several single-site fungicide groups such as triazoles, strobilurins, dicarboximides, phenylpyrroles, thiophanates, and multi-site fungicides such as mancozeb, captan, chlorothalonil, and copper (Denman et al. 2004; Syngenta 2016; Twizeyimana et al. 2013). However, fungicide sprays are often impractical due to lack of good coverage on large size trees, environmental exposure, and human exposure risks in vicinity of urban areas. In addition, sprays are usually ineffective if applied after the pathogen has infected and invaded internal tree tissues. Preventive application of systemic fungicides by trunk injection is slowly gaining popularity in recent decades but has not been studied widely enough to support commercial applications, primarily due to very limited number of xylem mobile and injectable formulations of fungicides (Aćimović et al. 2016b; Wyka et al. 2016). In the collected samples of symptomatic coast redwood trees and in our pathogenicity tests, Botryosphaeriaceae colonized the redwood xylem tissue, agreeing with reports on xylem invasion of other hosts and coast redwood (Czemmel et al. 2015; Larignon et al. 2015; McDonald and Eskalen 2011; Zlatković et al. 2016b).

This study on the occurrence of Botryosphaeriaceae species associated with coast redwood canker and dieback in California is significant in that five different pathogens were confirmed. In addition to $B$. dothidea, $N$. australe, $N$. luteum, $N$. mediterraneum, and $N$. parvum were all detected for the first time on this host in CA, with $N$. mediterraneum found for the first time worldwide as pathogen of coast redwood. These results confirm the rising incidence of different Botryosphaeriaceae plant pathogenic fungi in recent decades, deeming them an economic threat to California's agriculture and landscapes with plant communities under severe environmental stresses such as drought, fires, and floods (Chen et al. 2014b; Deamer 2016; Hanak et al. 2016; Lawrence et al. 2017; Lynch et al. 2013; McDonald et al. 2009; Moral et al. 2017; Úrbez-Torres et al. 2010a, b). Currently, there are no widely recommended practices for the prevention of coast redwood canker and dieback in urban stands. More research is needed to understand the biology of Neofusicoccum fungi on coast redwood, which in turn will allow development of effective disease management strategies and promote the improvement of horticultural practices in urban coast redwood stands.

\section{Acknowledgments}

We thank regional sales representatives of Arborjet Inc. for help in selecting the most affected locations in California with declining coast redwood trees and for collecting part of the infected samples. We thank faculty and staff of University of Florida's Plant Diagnostic Center in Gainesville, FL, for conducting gene sequencing for part of the isolates.

\section{Literature Cited}

Aćimović, S. G., Harmon, C. L., Bec, S., Wyka, S., Broders, K., and Doccola, J. J. 2016a. First report of Diplodia corticola causing decline of red oak (Quercus rubra) trees in Maine. Plant Dis. 100:649.

Aćimović, S. G., VanWoerkom, A. H., Garavaglia, T., Vandervoort, C., Sundin, G. W., and Wise, J. C. 2016b. Seasonal and cross-seasonal timing of 
fungicide trunk injections in apple trees to optimize management of apple scab. Plant Dis. 100:1606-1616.

Albu, S., Schneider, R. W., Price, P. P., and Doyle, V. P. 2016. Cercospora $\mathrm{cf}$. flagellaris and Cercospora cf. sigesbeckiae are associated with Cercospora leaf blight and purple seed stain on soybean in North America. Phytopathology 106:1376-1385.

Alves, A., Barradas, C., Phillips, A. J. L., and Correia, A. 2013. Diversity of Botryosphaeriaceae species associated with conifers in Portugal. Eur. J. Plant Pathol. 135:791-804.

Amponsah, N. T., Jones, E. E., Ridgway, H. J., and Jaspers, M. V. 2012. Susceptibility of grapevine tissues to Neofusicoccum luteum conidial infection. Plant Pathol. 61:719-729.

Berraf-Tebbal, A., Guerreiro, M. A., and Phillips, A. J. L. 2014. Phylogeny of Neofusicoccum species associated with grapevine trunk diseases in Algeria, with description of Neofusicoccum algeriense sp. nov. Phytopathol. Mediterr. 53:416-427.

Blackburn, L. 2010. Native Plant Highlights - Coast redwood (Sequoia sempervirens). Conservation Notes 17:8. http://yamhillswcd.org/wp-content/ uploads/2017/12/2010-Winter-Newsletter-2010.pdf. Accessed July 18, 2018.

Carbone, I., and Kohn, L. M. 1999. A method for designing primer sets for speciation studies in filamentous ascomycetes. Mycologia 91:553-556.

Castresana, J. 2000. Selection of conserved blocks from multiple alignments for their use in phylogenetic analysis. Mol. Biol. Evol. 17:540-552.

Chen, S. F., Morgan, D. P., Hasey, J. K., Anderson, K., and Michailides, T. J. 2014a. Phylogeny, morphology, distribution, and pathogenicity of Botryosphaeriaceae and Diaporthaceae from English walnut in California. Plant Dis. 98:636-652.

Chen, S. F., Morgan, D. P., and Michailides, T. J. 2014b. Botryosphaeriaceae and Diaporthaceae associated with panicle and shoot blight of pistachio in California, USA. Fungal Divers. 67:157-179.

Crous, P. W., Slippers, B., Groenewald, J. Z., and Wingfield, M. J. 2017. Botryosphaeriaceae: Systematics, pathology, and genetics. Fungal Biol. 121:305-306.

Czemmel, S., Galarneau, E. R., Travadon, R., McElrone, A. J., Cramer, G. R., and Baumgartner, K. 2015. Genes expressed in grapevine leaves reveal latent wood infection by the fungal pathogen Neofusicoccum parvum. PLoS One 10: e0121828

Darriba, D., Taboada, G. L., Doallo, R., and Posada, D. 2012. jModelTest2: More models, new heuristics and parallel computing. Nat. Methods 9:772.

Davidson, J. M., Patterson, H. A., and Rizzo, D. M. 2008. Sources of inoculum for Phytophthora ramorum in a redwood forest. Phytopathology 98:860-866.

Deamer, K. 2016. California's long drought has killed 100 million trees. Live Sci. https://www.livescience.com/57124-california-drought-killed-100-milliontrees.html. Accessed January 23, 2018.

Denman, S., Crous, P. W., Sadie, A., and Wingfield, M. J. 2004. Evaluation of fungicides for the control of Botryosphaeria protearum on Protea magnifica in the Western Cape Province of South Africa. Australas. Plant Pathol. 33: 97-102.

Dirr, M. A. 1990. Manual of Woody Landscape Plants: Their Identification, Ornamental Characteristics, Culture, Propagation and Uses, 4th Ed. Stipes Publishing Co., Champaign, IL.

Dissanayake, A. J., Phillips, A. J. L., Li, X. H., and Hyde, K. D. 2016. Botryosphaeriaceae: Current status of genera and species. Mycosphere. 7: 1001-1073.

Downer, J. 2004. What's up with redwoods? Landscape Notes no. 18. http:// ceventura.ucanr.edu/newsletters/Vol_18_No1_-_September_200429832.pdf. Accessed January 23, 2018.

Edgar, R. 2004. MUSCLE: Multiple sequence alignment with high accuracy and high throughput. Nucleic Acids Res. 32:1792-1797.

Elena, G., and Luque, J. 2016. Seasonal susceptibility of grapevine pruning wounds and cane colonization in Catalonia, Spain following artificial infection with Diplodia seriata and Phaeomoniella chlamydospora. Plant Dis. 100: 1651-1659.

Espinosa-Garcia, F. J., and Langenheim, J. H. 1990. The endophytic fungal community in leaves of a coastal redwood population diversity and spatial patterns. New Phytol. 116:89-97.

Farjon, A., and Schmid, R. 2013. Sequoia sempervirens. The IUCN Red List of Threatened Species 2013: e.T34051A2841558. Available at: http://www. iucnredlist.org/details/34051/0. Accessed December 15, 2017.

Farr, D. F., and Rossman, A. Y. 2017. Fungal Databases, US National Fungus Collections. ARS. USDA. https://nt.ars-grin.gov/fungaldatabases/. Accessed January 23, 2018.

Fichtner, E. J., Lynch, S. C., and Rizzo, D. M. 2007. Detection, distribution, sporulation, and survival of Phytophthora ramorum in a California redwoodtanoak forest soil. Phytopathology 97:1366-1375.

Golzar, H., and Burgess, T. I. 2011. Neofusicoccum parvum, a causal agent associated with cankers and decline of Norfolk Island pine in Australia. Australas. Plant Pathol. 40:484-489.

Guindon, S., and Gascuel, O. 2003. A simple, fast and accurate method to estimate large phylogenies by maximum-likelihood. Syst. Biol. 52:696-704

Hanak, E., Mount, J., and Chappelle, C. 2016. California's Latest Drought. Public Policy Inst. Calif. http://www.ppic.org/publication/californias-latest-drought/. Accessed January 23, 2018.
Hänzi, M., Pelleteret, P., and Lefort, F. 2016. Botryosphaeria dothidea et Botryosphaeria parva, agents de dépérissement des séquoias géants. Fact Sheet, University of Applied Sciences and Arts Western Switzerland, Delémont, Switzerland.

Herbert, B. 2014. Redwood champions amid drought and climate change Mountain Echo: The Newsletter of Sempervirens Fund. Fall 2014:3-6.

Huelsenbeck, J. P., and Ronquist, F. 2001. MrBayes: Bayesian inference of phylogenetic trees. Bioinformatics 17:754-755.

Inderbitzin, P., Bostock, R. M., Trouillas, F. P., and Michailides, T. J. 2010. A six locus phylogeny reveals high species diversity in Botryosphaeriaceae from California almond. Mycologia 102:1350-1368.

Jones, J. 2015. California's most significant droughts: Comparing historical and recent conditions. California Department of Water Resources, State of California. https://water.ca.gov/LegacyFiles/waterconditions/docs/California Signficant_Droughts_2015_small.pdf

Larignon, P., Spagnolo, A., Bertsch, C., and Fontaine, F. 2015. First report of young grapevine decline caused by Neofusicoccum parvum in France. Plant Dis. 99:1859.

Lawrence, D. P., Peduto Hand, F., Gubler, W. D., and Trouillas, F. P. 2017 Botryosphaeriaceae species associated with dieback and canker disease of bay laurel in northern California with the description of Dothiorella californica sp. nov. Fungal Biol. 121:347-360.

Lazzizera, C., Frisullo, S., Alves, A., and Phillips, A. J. L. 2008. Morphology, phylogeny and pathogenicity of Botryosphaeria and Neofusicoccum species associated with drupe rot of olives in southern Italy. Plant Pathol. 57: 948-956.

Lichter, J., and Evans, R. 2011. Horticultural considerations for utilizing coast redwood in northern California landscapes. Tree Assoc. Blog. https:// treeassociates.wordpress.com/2011/11/16/horticultural-considerations-forutilizing-coast-redwood-in-northern-california-landscapes/. Accessed December $28,2017$.

Linaldeddu, B. T., Maddau, L., and Franceschini, A. 2017. First report of Diplodia corticola causing canker and dieback of Quercus ilex, Q. petraea, and $Q$. suber in Corsica (France). Plant Dis. 101:256.

Lynch, S. C., Eskalen, A., Zambino, P., and Scott, T. 2010. First report of bot canker caused by Diplodia corticola on coast live oak (Quercus agrifolia) in California. Plant Dis. 94:1510.

Lynch, S. C., Eskalen, A., Zambino, P. J., Mayorquin, J. S., and Wang, D. H. 2013. Identification and pathogenicity of Botryosphaeriaceae species associated with coast live oak (Quercus agrifolia) decline in southern California. Mycologia 105:125-140.

Ma, Z., and Michailides, T. J. 2002. Characterization of Botryosphaeria dothidea isolates collected from pistachio and other plant hosts in California Phytopathology 92:519-526.

Ma, Z., Morgan, D. P., and Michailides, T. J. 2001. Effects of water stress on Botryosphaeria blight of pistachio caused by Botryosphaeria dothidea. Plant Dis. 85:745-749.

Maloney, P. E., Lynch, S. C., Kane, S. F., Jensen, C. E., and Rizzo, D. M. 2005 Establishment of an emerging generalist pathogen in redwood forest communities. J. Ecol. 93:899-905

Maloney, P. E., Rizzo, D. M., Koike, S. T., Harnik, T. Y., and Garbelotto, M. 2002 First report of Phytophthora ramorum on coast redwood in California. Plant Dis. $86: 1274$

Marshall, J., and Zambino, P. 2011. Seiridium canker. Pages 39-40 in: California Forest Pest Conditions 2011. A publication of the California Forest Pest Council https://www.fs.usda.gov/Internet/FSE_DOCUMENTS/stelprdb5362126.pdf. Accessed January 24, 2018.

Martin, D. K. H., Turcotte, R. M., Miller, T. M., Munck, I. A., Aćimović, S. G., Macias, A. M., Stauder, C. M., and Kasson, M. T. 2017. First report of Diplodia corticola causing stem cankers and associated vascular occlusion of northern red oak (Quercus rubra) in West Virginia. Plant Dis. 101:380.

McDonald, V., and Eskalen, A. 2011. Botryosphaeriaceae species associated with avocado branch cankers in California. Plant Dis. 95:1465-1473.

McDonald, V., Lynch, S., and Eskalen, A. 2009. First report of Neofusicoccum australe, $N$. luteum, and $N$. parvum associated with avocado branch canker in California. Plant Dis. 93:967.

Michailides, T. J. 1991. Pathogenicity, distribution, sources of inoculum, and infection courts of Botryosphaeria dothidea on Pistachio. Phytopathology 81: 566-573.

Michailides, T. J., and Morgan, D. P. 1993. Spore release by Botryosphaeria dothidea in pistachio orchards and disease control by altering the trajectory angle of sprinklers. Phytopathology 83:145-152.

Miller, M. A., Pfeiffer, W., and Schwartz, T. 2010. Creating the CIPRES Science Gateway for inference of large phylogenetic trees. Pages 1-8 in: Proceedings of the Gateway Computing Environments GCE Workshop, 14 Nov. 2010, New Orleans, LA.

Moral, J., Ahimera, N., Felts, D. G., Morgan, D. P., and Michailides, T. J. 2017 Effects of wound size, amount of sap, and number of blighted nuts on infection of pistachio organs by Neofusicoccum mediterraneum. Plant Dis. 101:2027-2033.

Moral, J., Muñoz-Díez, C., González, N., Trapero, A., and Michailides, T. J. 2010 Characterization and pathogenicity of Botryosphaeriaceae species collected from olive and other hosts in Spain and California. Phytopathology 100: $1340-135$ 
Moricca, S., Linaldeddu, B. T., Ginetti, B., Scanu, B., Franceschini, A., and Ragazzi, A. 2016. Endemic and emerging pathogens threatening cork oak trees: Management options for conserving a unique forest ecosystem. Plant Dis. 100:2184-2193.

Munck, I. A., Wyka, S. A., Bohne, M. J., Green, W. J., and Siegert, N. W. 2017. First report of Diplodia corticola causing bleeding cankers on black oak (Quercus velutina). Plant Dis. 101:257.

van Niekerk, J. M., Crous, P. W., Groenewald, J. Z., Fourie, P. H., and Halleen, F. 2004. DNA phylogeny, morphology and pathogenicity of Botryosphaeria species on grapevines. Mycologia 96:781-798.

Panzavolta, T., Panichi, A., Bracalini, M., Croci, F., Ginetti, B., and Ragazzi, A. 2017. Dispersal and propagule pressure of Botryosphaeriaceae species in a declining oak stand is affected by insect vectors. Forests $8: 228$.

Pavlic, D., Slippers, B., Coutinho, T. A., and Wingfield, M. J. 2009. Multiple gene genealogies and phenotypic data reveal cryptic species of the Botryosphaeriaceae: A case study on the Neofusicoccum parvum/N. ribis complex. Mol. Phylogenet. Evol. 51:259-268.

Phillips, A. J. L., Alves, A., Abdollahzadeh, J., Slippers, B., Wingfield, M. J., Groenewald, J. Z., and Crous, P. W. 2013. The Botryosphaeriaceae: genera and species known from culture. Stud. Mycol. 76:51-167.

Roa, M. 2007. Mid-twentieth century logging and the beginnings of modern resource management. Page 149 in: Redwood Ed - A Guide to the Coast Redwoods for Teachers and Learners. Stewards of the Coast and Redwoods, Duncans Mills, CA.

Rolshausen, P. E., Urbez-Torres, J. R., Rooney-Latham, S., Eskalen, A., Smith, R. J., and Gubler, W. D. 2010. Evaluation of pruning wound susceptibility and protection against fungi associated with grapevine trunk diseases. Am. J. Enol. Vitic. 61:113-119.

Ronquist, F., and Huelsenbeck, J. P. 2003. MrBayes 3: Bayesian phylogenetic inference under mixed models. Bioinformatics 19:1572-1574.

Ronquist, F., Teslenko, M., van der Mark, P., Ayres, D. L., Darling, A., Hohna, S., Larget, B., Liu, L., Suchard, M. A., and Huelsenbeck, J. P. 2012. MrBayes 3.2: Efficient Bayesian phylogenetic inference and model choice across a large model space. Syst. Biol. 61:539-542.

Rooney-Latham, S., Tidwell, T. E., Blomquist, C. L., and Peek, K. S. 2012. First report of Neofusicoccum nonquaesitum causing branch cankers on giant sequoia (Sequoiadendron giganteum) in North America. Plant Dis. 96:905.

Sakalidis, M. L., Hardy, G. E. S., and Burgess, T. I. 2011. Class III endophytes, clandestine movement amongst hosts and habitats and their potential for disease; a focus on Neofusicoccum australe. Australas. Plant Pathol. 40:510-521.

Scharpf, R. F. 1993. Diseases of Pacific Coast conifers. Rev. June 1993. USDA, Forest Service, Washington, DC.

Schoeneweiss, D. F. 1975. A method for controlling plant water potentials for studies on the influence of water stress on disease susceptibility. Can. J. Bot. 53:647-652.

Schoeneweiss, D. F. 1981. The role of environmental stress in diseases of woody plants. Plant Dis. 65:308-314.

Shearer, B. F., and Shearer, B. S. 2002. State names, seals, flags, and symbols, 3rd Ed. Greenwood Press, Westport, CT. http://agris.fao.org/agris-search/search. do?recordID=US201300167689. Accessed December 13, 2017.

Sillett, S. C., Van Pelt, R., Koch, G. W., Ambrose, A. R., Carroll, A. L., Antoine, M. E., and Mifsud, B. M. 2010. Increasing wood production through old age in tall trees. For. Ecol. Manage. 259:976-994.

Sinclair, W. A., and Lyon, H. H. 2005. Diseases of trees and shrubs, 2nd Ed. Cornell University Press, Ithaca, NY.

Slippers, B., Roux, J., Wingfield, M. J., van der Walt, F. J. J., Jami, F., and Mehl, J. W. M. 2014. Confronting the constraints of morphological taxonomy in the Botryosphaeriales. Persoonia Mol. Phylogeny Evol. Fungi. 33:155-168.

Slippers, B., Smit, W. A., Crous, P. W., Coutinho, T. A., Wingfield, B. D., and Wingfield, M. J. 2006. Taxonomy, phylogeny and identification of Botryosphaeriaceae associated with pome and stone fruit trees in South Africa and other regions of the world. Plant Pathol. 56:128-139.

Slippers, B., Summerel, B. A., Crous, P. W., Coutinho, T. A., Wingfield, B. D., and Wingfield, M. J. 2005. Preliminary studies on Botryosphaeria species from Southern Hemisphere conifers in Australasia and South Africa. Australas. Plant Pathol. 34:213-220.

Stamatakis, A. 2006. RAxML-VI-HPC: Maximum likelihood-based phylogenetic analyses with thousands of taxa and mixed models. Bioinformatics 22:2688-2690.

Stephenson, N. L., Das, A. J., Condit, R., Russo, S. E., Baker, P. J., and Beckman, N. G. 2014. Rate of tree carbon accumulation increases continuously with tree size. Nature 507:90-93.
Sutton, T. B., Aldwinckle, H. S., Agnello, A. M., and Walgenbach, J. F. 2014 Compendium of Apple and Pear Diseases and Pests. American Phytopathological Society, St. Paul, MN.

Syngenta. 2016. Syngenta Guide to Ornamental Fungicides. http://staugorchidsociety. org/PDF/2016SyngentaGuidetoOrnamentalFungicides.pdf. Accessed January 24 2018

Talavera, G., and Castresana, J. 2007. Improvement of phylogenies after removing divergent and ambiguously aligned blocks from protein sequence alignments. Syst. Biol. 56:564-577.

Tamura, K., Stecher, G., Peterson, D., Filipski, A., and Kumar, S. 2013. MEGA6: Molecular evolutionary genetics analysis version 6.0. Mol. Biol. Evol. 30: 2725-2729.

Tobiessen, P., and Buchsbaum, S. 1976. Ash dieback and drought. Can. J. Bot. 54: 543-545.

Twizeyimana, M., McDonald, V., Mayorquin, J. S., Wang, D. H., Na, F., Akgül, D. S., and Eskalen, A. 2013. Effect of fungicide application on the management of avocado branch canker (formerly Dothiorella canker) in California. Plant Dis. 97:897-902

UC IPM. 2016. Managing Pests in Gardens: Trees and Shrubs: Coast redwood-Sequoia sempervirens. http://ipm.ucanr.edu/PMG/GARDEN/PLANTS/ redwood.html. Accessed December 28, 2017.

Úrbez-Torres, J. R., and Gubler, W. D. 2009. Pathogenicity of Botryosphaeriaceae species isolated from grapevine cankers in California. Plant Dis. 93:584-592.

Úrbez-Torres, J. R., and Gubler, W. D. 2011. Susceptibility of grapevine pruning wounds to infection by Lasiodiplodia theobromae and Neofusicoccum parvum. Plant Pathol. 60:261-270.

Úrbez-Torres, J. R., Peduto, F., and Gubler, W. D. 2010a. First report of grapevine cankers caused by Lasiodiplodia crassispora and Neofusicoccum mediterraneum in California. Plant Dis. 94:785.

Úrbez-Torres, J. R., Peduto, F., Rooney-Latham, S., and Gubler, W. D. 2010b. First report of Diplodia corticola causing grapevine (Vitis vinifera) cankers and trunk cankers and dieback of canyon live oak (Quercus chrysolepis) in California. Plant Dis. 94:785.

Úrbez-Torres, J. R., Peduto, F., Vossen, P. M., Krueger, W. H., and Gubler, W. D 2013. Olive twig and branch dieback: etiology, incidence, and distribution in California. Plant Dis. 97:231-244.

Van Pelt, R., Sillett, S. C., Kruse, W. A., Freund, J. A., and Kramer, R. D. 2016 Emergent crowns and light-use complementarity lead to global maximum biomass and leaf area in Sequoia sempervirens forests. For. Ecol. Manage. 375:279-308.

Wene, E. G. 1979. Stress predisposition of woody plants to stem canker caused by Botryosphaeria dothidea. Ph.D. Thesis, University of Illinois, Urbana.

Wene, E. G., and Schoeneweiss, D. F. 1980. Localized freezing predisposition to Botryosphaeria canker in differentially frozen woody stems. Can. J. Bot. 58: $1455-1458$

White, T. J., Bruns, T. D., Lee, S. B., and Taylor, J. W. 1990. Amplification and direct sequencing of fungal ribosomal RNA genes for phylogenetics. Pages 315-322 in: PCR Protocols: A Guide to Methods and Applications. M. A. Innis, D. H. Gelfand, J. J. Sninsky, and T. J. White, eds. Academic Press, San Diego, CA

Worrall, J. J., Correll, J. C., and McCain, A. H. 1986. Pathogenicity and telemorphanamorph connection of Botryosphaeria dothidea on Sequoiadendron giganteum and Sequoia sempervirens. Plant Dis. 70:757-759.

Wyka, S. A., Doccola, J. J., Strom, B. L., Smith, S. L., McPherson, D. W., Aćimović, S. G. 2016. Effects of Grosmannia clavigera and Leptographium longiclavatum on western white pine seedlings and the fungicidal activity of Alamo $^{\circledR}$, Arbotect $^{\circledR}$, and TREE-age ${ }^{\circledR}$. Arboric. Urban For. 42:84-94.

Yan, J. Y., Zhao, W. S., Chen, Z., Xing, Q. K., Zhang, W., and Chethana, K. W. T. 2018. Comparative genome and transcriptome analyses reveal adaptations to opportunistic infections in woody plant degrading pathogens of Botryosphaeriaceae. DNA Res. 25:87-102

Zhang, M., Lin, S., He, W., and Zhang, Y. 2017. Three species of Neofusicoccum (Botryosphaeriaceae, Botryosphaeriales) associated with woody plants from southern China. Mycosphere. 8:797-808.

Zlatković, M., Keča, N., Wingfield, M. J., Jami, F., and Slippers, B. 2016a Botryosphaeriaceae associated with the die-back of ornamental trees in the Western Balkans. Antonie van Leeuwenhoek 109:543-564.

Zlatković, M., Keča, N. D., Wingfield, M. J., Fahimeh, J., and Slippers, B. 2016b. Botryosphaeriaceae on Sequoia sempervirens in Serbia. Conference paper for the Belgrade BioInformatics Conference - BelBi, 20-24 Jun, Belgrade, Serbia. 